\title{
In memoriam: Prof. Dr. Luis Gramática
}

\author{
Francisco Florez Nicolini, Paul Lada
}

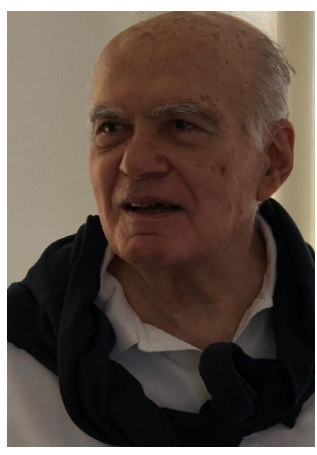

Expresidente de la Asociación Argentina de Cirugía

Es un gran honor poder expresar la trayectoria de un eximio maestro de la cirugía de Córdoba, de nuestro país y del mundo entero, quien ha sido para nosotros -además de nuestro mentor en cirugía- un permanente apoyo y un consejero y amigo inconmensurable.

Luis Gramática nació en Villa Dolores, una ciudad del oeste cordobés, el 14 de noviembre de 1940. Hijo de Ferrante José Gramatica y Sara Ema Mateos por los cuales sentía una pasión especial, cursó allí sus estudios primarios y secundarios para luego ingresar en la Facultad de Ciencias Médicas de la Universidad Nacional de Córdoba donde fue un alumno destacado. Al terminar sus estudios, comenzó a trabajar en la Cátedra de Anatomía Descriptiva, donde tuvimos la oportunidad de conocerlo. No pasaba inadvertido e impresionaba con sus conocimientos y la facilidad con que los exponía. A su vez inició su actividad como cirujano, incorporándose como médico del Servicio de Cirugía $N^{\circ}$ 2 del Hospital de Clínicas de Córdoba, que años atrás había fundado el Dr. Pablo Luis Mirizzi, y continuó rigurosamente su escuela.

Luego de un tiempo decide completar su formación quirúrgica en España y logra ingresar en el Hospital de la Santa Cruz y San Pablo, en el Servicio de Cirugía General y Digestiva, que dirigía en ese momento el Profesor Jaime Pi Figueras, quien poseía un reconocimiento mundial y a quien Luis consideraba su verdadero maestro. Conoce en el Hospital a Concepción Bosch, con quien se casa y que fue su inseparable compañera a través del tiempo. Tuvo tres hijos: Luis, quien siguió la actividad quirúrgica junto a él, Gabriel y Gerard, estos últimos prestigiosos abogados en la ciudad de Córdoba.
Terminado su entrenamiento en Barcelona, emigra a los Estados Unidos, donde es recibido en la Norwestern University de Chicago; allí se dedica de lleno a la investigación en enfermedades pancreáticas bajo la dirección del Prof. Marion Anderson. Luego viaja a Francia para completar esos estudios junto al Prof. Henry Sarles, en Marsella.

Tiempo después vuelve a Córdoba, donde al poco tiempo expone su Tesis Doctoral titulada Colecistopancreatitis, que obtiene la máxima calificación. Esta circunstancia y su pasión por el páncreas lo llevan a ocupar los principales estrados de la comunidad quirúrgica.

También se propuso desarrollar una experiencia en cirugía de colon, recto y ano en el Hospital San Mark de Londres. Posteriormente ganó por concurso la beca JICA que lo llevó a Japón y, bajo la dirección del Prof. Endo, realizó una importante experiencia en cirugía esófago-gástrica.

De regreso a Córdoba, gana por concurso el cargo de Profesor Titular de la II Cátedra de Clínica Quirúrgica y, posteriormente, asume como Jefe del Servicio de Cirugía.

Pero quizás, sus viajes más importantes como comentaba con pasión, junto a las experiencias que lo dejarían marcado para siempre, fueron los que hacía a África en compañía de uno de sus discípulos más queridos, el Dr. Ernesto Papa. No hay duda de que dejó ayudas de tremenda magnitud, asistiendo y operando a numerosos enfermos en misiones humanitarias en Camerún y Mali.

Tenía un especial cariño por la Asociación Argentina de Cirugía, donde se desempeñó en el año 
2001 como presidente del $72^{\circ}$ Congreso Argentino de Cirugía y 2 años más tarde llegó a la Presidencia de la Institución.

Pero, para él, lo más importante en su trayectoria médica fue su dedicación a la formación de nuevas generaciones. Permanentemente se preguntaba qué era lo mejor para poder ofrecerles. Así pudo enviar a numerosos médicos para realizar experiencias en importantes centros, tanto en el país como en el exterior. Formó numerosos discípulos entre los que nos encontramos -junto a profesionales de dilatada trayectoria como Orlando Mdalel- Jorge Saliba, Rolando Montenegro, su hijo Luisito, Roberto Badra, Francisco Bergesio, Daniel Beyrne, Cristian Dutari, Federico Garibotti y muchísimos más. Era un placer acompañarlo en una visita de sala. Siempre deslumbraba con su habilidad para resolver los casos problema, y sus propuestas diagnósticas eran de una solidez increíble. Cuando su- bíamos a quirófano, nos impresionaba con su destreza y por la precisión en aplicar una técnica quirúrgica. Una actividad que disfrutaba era la de compartir un café con todos sus discípulos en el bar frente al hospital, después de las recorridas de sala o al finalizar una cirugía. Eran verdaderos ateneos en los cuales participábamos la mayoría de los médicos de una manera muy distendida, y él cariñosamente las llamaba Charlas de Ortega y Gasset.

Su preocupación fue siempre asistir a los cirujanos. Estaba presente apenas se lo necesitaba y ayudó desinteresadamente a muchísimos, tanto ante una dificultad, como frente a una grave complicación.

Querido Luis, siempre te recordaremos con un cariño inmenso, un gran respeto y una profunda admiración.

Que descanses en paz.

\section{- ENGLISH VERSION}

It is a great honor to put into words the trajectory of an outstanding master of surgery of Cordoba, of our country and of the entire world, who has been not only our mentor in surgery, but also a permanent support and an immeasurable advisor and friend.

Luis Gramática was born in Villa Dolores, a city in western Cordoba, on November 14, 1940. He was the son of Ferrante José Gramatica and Sara Ema Mateos, for whom he had a special passion. He completed his primary and secondary education there and then entered the Faculty of Medicine of the Universidad Nacional de Córdoba, where he was an outstanding student. When he finished his studies, he started working in the Chair of Descriptive Anatomy, where we had the opportunity to meet him. He did not go unnoticed and impressed us with his knowledge and the ease he displayed. At the same time, he started his activity as a surgeon, joining the Surgery Department 2 of the Hospital de Clínicas de Córdoba, which had been established by Dr. Pablo Luis Mirizzi years before, and continued with his rigorous way of teaching.

After some time, he decided to complete his surgical training in Spain and managed to enter the Hospital de la Santa Cruz y San Pablo, in the Department of General and Digestive Surgery, under the direction of Professor Jaime Pi Figueras, who was recognized worldwide and was considered by Luis to be his true master. There he met Concepción Bosch, who he married and who was his inseparable partner over time. He had three children: Luis, who became a surgeon and worked with him, and Gabriel and Gerard, two renowned lawyers in the city of Cordoba.

After finishing his training in Barcelona, he moved to the United States, where he received his degree from Norwestern University at Chicago. There, he was fully dedicated to research on pancreatic diseases under the supervision of Prof. Marion Anderson. He then travelled to France to complete his studies with Prof. Henry Sarles in Marseille.

Sometime later he returned to Cordoba, where he soon presented his doctoral thesis entitled Cholecystopancreatitis, which obtained the highest qualification. This achievement and his passion for the pancreas placed him on the leading positions among the surgical community.

He also went to St Mark's Hospital in London where he received training in colorectal surgery. Later, he won the JICA scholarship and moved to Japan where he gained important experience in esophageal and gastric surgery under the supervision of Prof. Endo.

Back in Córdoba, he became Full Professor of the II Chair of Clinical Surgery by competitive selection, and later became head of the Department of Surgery.

But perhaps his trips to Africa in the company of one of his most beloved disciples, Dr. Ernesto Papa, were the most important experiences that would mark him forever, as he commented with passion. Undoubtedly, he provided invaluable help by assisting and operating on many sick people in humanitarian missions in Cameroon and Mali.

He had a special affection for Asociación Argentina de Cirugía, where he acted as president of the $72^{\text {nd }}$ Argentine Congress of Surgery in 2001, and two years later he became president of the institution.

But his dedication to training new generations was the most important aspect of his medical career. He constantly asked himself what he could offer them best. In this way, he was able to make several doctors work in important centers in the country and abroad. He educated many trainees, including professionals with a 
considerable trajectory as Orlando Mdalel, Jorge Saliba, Rolando Montenegro, his son Luisito, Roberto Badra, Francisco Bergesio, Daniel Beyrne, Cristian Dutari and Federico Garibotti, among others. It was a pleasure to accompany him on a ward round. He always impressed us with his ability to solve problematic cases, and his differential diagnoses were absolutely solid. When we entered the operating room, he impressed us with his skill and precision in applying a surgical technique. He enjoyed sharing a coffee with all his trainees at the bar in front of the hospital after ward rounds or at the end of a surgery. They were real clinical seminars in which most of the physicians participated very relaxed, and he lovingly called these meetings Ortega y Gasset's Chats.

He was always concerned about assisting surgeons. He was present as soon as he was needed and generously helped many of them with any difficulty or serious complication.

Dear Luis, we will always remember you with great affection, intense respect and deep admiration.

May you rest in peace. 